\title{
PENGARUH ZAKAT PERBANKAN DAN CORPORATE SOCIAL RESPONSIBILITY TERHADAP RASIO PROFITABILITAS BANK UMUM SYARIAH DI INDONESIA
}

\author{
THE EFFECT OF BANKING ZAKAT AND CORPORATE SOCIAL \\ RESPONSIBILITY ON THE PROFITABILITY RATIO OF SHARIA \\ COMMERCIAL BANKS IN INDONESIA
}

\author{
Windari, Abdul Nasser Hasibuan \\ IAIN Padangsidimpuan \\ Jalan Imam Bonjol KM.4,5 Sihitang Padangsidimpuan \\ wwindariok@gmail.com, abdulnaserhasibuan@gmail.com
}

Naskah diterima 22 Februari 2021, di-review 24 Mei 2021, disetujui 30 Juni 2021

\begin{abstract}
This research is supported by not fit the theory to fact. Based on data obtained from syariah commercial banks in indonesia as much as the percentage of the charity bank 9, banking corporate social responsibility and return on assets in fluctuation, but the increase that happened to the charity banking and corporate social responsibility is not always followed by increase return on assets. The study aimed to identify the charity banking and corporate social responsibility to the ratio of profitability syariah commercial banks in indonesia 2013-2018 good on this fact and simultaneously. This research is quantitative research, the data derived from secondary data with the data format + cross-section 2013-2018 years time series. Data analysis techniques in a regression panel estimate data, with the tand the f. as using software analyzed eviews 9 . The result showed on this fact charity banks significant impact on return on assets syariah commercial banks in indonesia, corporate social responsibility on this fact no significant impact on return on assets syariah commercial banks in indonesia. Simultaneous meanwhile zakat banking and corporate social responsibility having significant influence to return on assets syariah commercial bank in indonesia the $R^{2}$ of 0.633020 or 63.30 percent and 36.70 percent affected by other variables that not discussed in this study.
\end{abstract}

Keywords : Zakat Banking, Corporate Social Responsibility and Return On Assets

\begin{abstract}
Abstrak: Penelitian ini dilatarbelakangi dengan tidak sesuainya teori dengan fakta. Berdasarkan data yang diperoleh dari Bank Umum Syariah di Indonesia sebanyak 9 bank persentase Zakat Perbankan, Corporate Social Responsibility dan Return On Asset mengalami fluktuasi, namun kenaikan yang terjadi pada Zakat Perbankan dan Corporate Social Responsibility tidak selalu diikuti dengan kenaikan Return On Asset. Penelitian ini bertujuan untuk mengetahui pengaruh zakat perbankan dan corporate social responsibility terhadap rasio profitabilitas Bank Umum Syariah di Indonesia 2013-2018 baik secara parsial maupun secara simultan. Penelitian ini adalah penelitian kuantitatif, sumber data berasal dari data sekunder dengan bentuk data time series + cross-section tahun 2013-2018. Teknik analisis data menggunakan metode estimasi regresi data panel, dengan uji t dan uji f. Yang dianalisis dengan menggunakan Software Eviews 9. Hasil penelitian menunjukkan secara parsial zakat perbankan berpengaruh signifikan terhadap return on asset Bank Umum Syariah di Indonesia, corporate social responsibility secara parsial tidak berpengaruh signifikan terhadap return on asset Bank Umum Syariah di Indonesia. Sedangkan secara simultan zakat perbankan dan corporate social responsibility memiliki pengaruh yang signifikan terhadap return on asset Bank Umum Syariah di Indonesia dengan nilai $\mathrm{R}^{2}$ sebesar 0.633020 atau 63.30 persen yang artinya 36.70 persen dipengaruhi oleh variabel lain yang tidak dibahas pada penelitian ini.
\end{abstract}

Kata Kunci: Zakat Perbankan, Corporate Social Responsibility dan Return On Asset 


\section{PENDAHULUAN}

$\mathfrak{B}^{\text {a }}$ ank adalah suatu badan usaha yang menghimpun dana dari masyarakat dalam bentuk simpanan dan menyalurkannya kembali kepada masyarakat dalam bentuk kredit atau bentuk lainnya dalam rangka meningkatkan taraf hidup rakyat. Hal ini sesuai dengan UndangUndang Perbankan No. 21 tahun 2008 tentang perbankan syariah. (Anggota Ikapi, 2008:39)

Kinerja keuangan bank merupakan salah satu komponen yang penting dalam kegiatan perbankan. Kinerja keuangan bank akan menunjukkan kemampuan suatu perusahaan dalam mengelola dan mengalokasikan sumber dayanya. Penilaian kinerja bank dilakukan dengan menganalisa dan mengevaluasi laporan keuangan. Rasio merupakan alat ukur yang digunakan untuk menganalisis laporan keuangan. Rasio menggambarkan suatu hubungan atau pertimbangan antara suatu jumlah tertentu dengan jumlah yang lain. Dengan menggunakan analisis berupa rasio keuangan dapat menjelaskan dan memberikan gambaran baik buruknya kinerja suatu bank dari suatu periode ke periode berikutnya. Salah satu rasio keuangan yang digunakan untuk melihat kemampuan bank dalam mengelola dana adalah rasio profitabilias yang diukur dengan return on asset.

Return on asset lebih memfokuskan pada kemampuan perusahaan untuk memperoleh earning dalam operasi perusahaan secara keseluruhan. Selain itu dalam penentuan tingkat kesehatan suatu bank, Bank Indonesia lebih mementingkan penilaian return on asset dari pada return on equity karena Bank Indonesia lebih mengutamakan nilai profitabilitas suatu bankyang diukur dengan asetnya yang dananya sebagian besar berasal dari dana simpanan masyarakat. (Ardhi Abdillah dkk, Jurnal Administrasi Bisnis (JAB), Vol. 25, No. 2 Agustus 2015:4)

Dalam perkembangannya return on asset pada bank umum syariah Indonesia mengalami fluktuasi dari tahun 2013-2018. Seperti yang terlihat dari tabel 1.1 dibawah ini:

Tabel 1.1

Return on asset Pada Bank Umum Syariah

\begin{tabular}{|l|l|l|l|l|l|l|}
\hline \multirow{2}{*}{ Nama Bank } & \multicolumn{7}{c|}{ Tahun } \\
\cline { 2 - 7 } & \multicolumn{1}{|c|}{$\mathbf{2 0 1 3}$} & \multicolumn{1}{|c|}{$\mathbf{2 0 1 4}$} & \multicolumn{1}{c|}{$\mathbf{2 0 1 5}$} & $\mathbf{2 0 1 7}$ & \multicolumn{2}{c|}{$\mathbf{2 0 1 8}$} \\
\hline PT. BMI & $0,50 \%$ & $0,17 \%$ & $0,20 \%$ & $0,22 \%$ & $0,11 \%$ & $0,08 \%$ \\
\hline PT. BNIS & $1,37 \%$ & $1,27 \%$ & $1,43 \%$ & $1,44 \%$ & $1,31 \%$ & $1,42 \%$ \\
\hline PT. BRIS & $1,15 \%$ & $0,08 \%$ & $0,77 \%$ & $0,95 \%$ & $0,51 \%$ & $0,43 \%$ \\
\hline PT. BMS & $1,14 \%$ & $1,16 \%$ & $1,97 \%$ & $2,63 \%$ & $1,56 \%$ & $0,93 \%$ \\
\hline PT. MBS & $2,87 \%$ & $3,61 \%$ & $2,13 \%$ & $9,51 \%$ & $5,5 \%$ & $6,68 \%$ \\
\hline PT. BPS & $1,03 \%$ & $1,99 \%$ & $1,14 \%$ & $0,37 \%$ & $-10,77 \%$ & $0,26 \%$ \\
\hline PT. BCAS & $0,1 \%$ & $0,8 \%$ & $1,0 \%$ & $1,1 \%$ & $1,2 \%$ & $1,2 \%$ \\
\hline PT. BAS & $3,44 \%$ & $3,22 \%$ & $2,83 \%$ & $2,48 \%$ & $2,51 \%$ & $2,38 \%$ \\
\hline PT. BBS & $0,69 \%$ & $0,27 \%$ & $0,79 \%$ & $1,12 \%$ & $0,02 \%$ & $0,02 \%$ \\
\hline
\end{tabular}

Sumber: Publikasi annual report masing-masing bank umum syariah (data diolah, 2020)

Berdasarkan tabel diatas dapat dilihat bahwa secara garis besar return on asset pada bank umum syariah menurun. Penurunan yang signifikan terjadi pada PT. Bank Panin Syariah yaitu pada tahun 2017 mengalami penurunan sebesar $10,40 \%$ dari tahun sebelumnya. 
Selain kinerja keuangan bank umum syariah terdapat hal yang harus diperhatikan yaitu kinerja sosial bank umum syariah. Salah satu kinerja sosial yang dilakukan oleh bank umum syariah adalah program tanggung jawab sosial perusahaan atau corporate social responsibility (CSR). Terbukti dengan adanya kewajiban bank syariah dalam mempublikasikan laporan sumber penggunaan dana zakat dan corporate social responsibility.

Zakat merupakan salah satu komponen dalam sistem kesejahteraan Islam. Apabila zakat benar-benar dikelola sebagaimana dicontohkan oleh Nabi SAW, niscaya ia akan meningkatkan kesejahteraan masyarakat, mengurangi pengangguran dan sekaligus mengurangi jumlah kaum fakir miskin. Apabila kesejahteraan meningkat sudah jelas kaum fakir miskin secara berangsur-angsur akan bisa berkurang. Dari sini dapat dilihat jelas bahwa zakat berperan besar dalam meningkatkan pertumbuhan ekonomi. (Umrotul Khasanah, 2010:52)

Zakat merupakan bagian dari konsep Corporate Social Responsibility (CSR) yang akan memberikan panduan pada perusahaan untuk memperhatikan kepentingan sosial disamping kepentingan perusahaan itu sendiri. Kedermawanan perusahaan diwadahi dan dilambangkan sebagai zakat pengusaha maupun perusahaan. Zakat merupakan suatu kewajiban bagi umat muslim yang tergolong mampu. (Didin Hafidhuddin, 2007:214)

Para ulama peserta Muktamar Internasional pertama tentang zakat, menganalogikan zakat perusahaan ini kepada zakat perdagangan, karena dipandang dari aspek legal dan ekonomi kegiatan sebuah perusahaan intinya berpijak pada kegiatan trading atau perdagangan. Maka perusahaan diwajibkan mengeluarkan zakat-nya. Dimana hal ini bisa kita lihat pada Bank Syariah yang mengeluarkan zakat perusahaan setiap tahunnya. Landasan hukum kewajiban zakat perusahaan terdapat dalam Undang-Undang No. 23 Tahun 2011, tentang Pengelolaan Zakat, Bab IV pasal 11 ayat (2) bagian (b) dikemukaan bahwa diantara objek zakat yang wajib dikeluarkan zakat-nya adalah perdagangan dan perusahaan. (Didin Hafidhuddin, 2002:101)

Bank Syariah merupakan salah satu bank yang melakukan pengelolaan terhadap dana zakat. Terbukti dengan adanya kewajiban bank syariah dalam mempublikasikan laporan sumber dan penggunaan dana zakat. Dana zakat tersebut merupakan zakat yang berasal dari internal maupun eksternal bank syariah. (Rizal Yaya, 2016:284)

Bank syariah atau perusahaan tidak hanya mengeluarkan dana zakat tetapi bank syariah atau perusahaan juga memiliki tanggung jawab sosial yang harus dipenuhinya sesuai dengan Pasal 74 ayat (1) Undang-Undang Perseroan Terbatas. (Hendrik Budi Untung, 2009:15)

Pada awal perkembangannya, program corporate social responsibility (CSR) yang paling umum dilaksanakan oleh perusahaan-perusahaan adalah pemberian bantuan sosial terhadap masyarakat yang hidup di sekitar perusahaan. Pendekatan corporate social responsibility yang berdasarkan pada sosial dan kemanusiaan ini pada umumnya dilakukan hanya untuk mempertahankan citra positif perusahaan dimata 
masyarakat. Pembentukan citra perusahaan yang ramah lingkungan dan peduli terhadap masyarakat yang tinggal disekitar tempat usaha akan membuat pengoperasian bisnis berjalan lancar. Cepat atau lambat, perusahaan tersebut akan menuai hasilnya yaitu peningkatan keuntungan bank syariah.

Citra positif perusahaan yang terbentuk tidak dapat direkayasa, karena citra akan datang dengan sendirinya dari upaya yang dilaksanakan oleh perusahaan, sehingga komunikasi dan keterbukaan perusahaan merupakan salah satu faktor utama untuk mendapat citra perusahan yang positif. Salah satu keuntungan apabila perusahaan menerapkan corporate sosial responsibility secara berkelanjutan meningkatkan dan menguatkan profitabilitas suatu perusahaan. (Cindy Widyastuti, Skripsi, Institut Agama Islam Negeri Surakarta, 2017:7)

Manfaat dari program corporate social responsibility ini khususnya Bank Umum Syariah mulai berbondong-bondong untuk melakukan kegiatan ini. Karena dengan melakukan kegiatan corporate social responsibility ini secara tidak langsung akan mendapat timbal balik yang awalnya berupa nama baik di masyarakat dan akhirnya masyarakat juga akan lebih percaya pada pihak yang mengeluarkan corporate social responsibility tersebut, dan memutuskan untuk melakukan berbagai transaksi perbankan di bank yang mengeluarkan corporate social responsibility tersebut, dengan demikian nasabah perbankan akan bertambah dan dengan otomatis pendapatan perbankan pun akan bertambah dan pastinya keuntungan yang didapat akan bertambah. (Hendrik Budi Untung, 2009: 15)

$64 \mid$ Windari, Abdul Nasser Hasibuan

\section{KERANGKA KONSEPTUAL}

\section{Kinerja Keuangan}

\section{Pengertian Kinerja Keuangan}

Kinerja keuangan secara keseluruhan merupakan gambaran prestasi yang dicapai bank dalam operasionalnya baik menyangkut aspek keuangan, pemasaran, penghimpunan dan penyaluran dana, teknologi maupun sumber daya manusia. (Irham Fahmi, 2011:24)

Kinerja keuangan adalah suatu analisis yang dilakukan untuk melihat sejauh mana suatu perusahaan telah melaksanakan dengan menggunakan aturan-aturan pelaksanaan keuangan secara baik dan benar. (Jumingan, 2011:239)

Dalam UU RI No. 7 Tahun 1992 tentang perbankan disebutkan bahwa Bank Indonesia berhak untuk menetapkan ketentuan tentang kesehatan bank dengan memperhatikan aspek permodalan, kualitas aset, rentabilitas, likuiditas, solvabilitas dan aspek lainnya yang berkaian dengan usaha bank. (Nizamulloh, Jurnal Akuntansi Vol 03. N0.2, 2014.)

Dari beberapa penilaian kinerja diatas dapat ditarik kesimpulan bahwa kinerja keuangan adalah gambaran kondisi keuangan atau prestasi suatu bank yang menjadi tolak ukur sejauh mana suatu bank mampu mengelola dan mengendalikan sumber daya yang dimilikinya.

\section{Pengukuran Kinerja Keuangan}

Pengukuran kinerja keuangan dilakukan bersamaan dengan proses analisis. Analisis kinerja keuangan merupakan suatu proses pengkajian kinerja secara kritis, yang meliputi 
peninjauan data keuangan, perhitungan, pengukuran, interprestasi dan pemberi solusi terhadap masalah keuangan perusahaan pada periode tertentu. (Hery, 2015:29).

Tujuan penilaian kinerja keuangan yaitu:

1. Untuk mengetahui keberhasilan pengelolaan keuangan perusahaan terutama kondisi likuiditas, kecukupan modal dan profitabilitas yang dicapai dalam tahun berjalan maupun tahun sebelumnya.

2. Untuk mengetahui kemampuan perusahaan dalam mendayagunakan semua aset yang dimiliki dalam menghasilkan profit secara efisien. (Jumingan, 2011:239)

Kinerja keuangan dapat dinilai dengan menggunakan beberapa alat analisis, salah satunya dengan menggunakan analisis rasio keuangan.

\section{Rasio Keuangan}

Rasio keuangan adalah angka yang diperoleh dari hasil perbandingan satu pos laporan keuangan dengan pos lainnya yang mempunyai hubungan yang relevan dan signifikan. Perbandingan dapat dilakukan antara satu pos dengan pos lainnya dalam satu laporan keuangan atau antar pos yang ada diantara laporan keuangan. Rasio keuangan adalah suatu kajian yang melihat perbandingan antara jumlah-jumlah yang terdapat pada laporan keuang dan dengan menggunakan formulaformula yang dianggap representatif untuk diterapkan. (Hery, 2011:161).

\section{Rasio Rentabilitas}

Rasio rentabilitas merupakan rasio yang digunakan untuk mengukur tingkat efisiensi usaha dan profitabilitas yang dicapai oleh bank yang bersangkutan. Rasio rentabilitas dikenal juga sebagai rasio profitabilitas. (Kasmir, 2012: 327)

Salah satu rasio rentabilitas yang digunakan untuk mengukur kemampuan perusahaan dalam menghasilkan laba adalah return on asset. Return on asset (ROA) adalah rasio yang digunakan untuk mengukur manajemen bank dalam memperoleh keuntungan (laba) secara keseluruhan. Semakin besar return on asset suatu bank, maka semakin besar pula tingkat keuntungan yang dicapai bank tersebut dan semakin baik pula posisi bank tersebut dari segi penggunaan asset. (Cindy Widyastuti, Skripsi IAIN Surakarta, 2017: 17)

Rasio Return On Asset dirumuskan sebagai berikut:

$$
\text { ROA }=\frac{\text { Laba Setelah Pajak }}{\text { Total Aset }} \times 100 \%
$$

\section{Zakat Perbankan}

Zakat merupakan ibadah maliyah yang mempunyai dimensi dan fungsi sosial ekonomi atau pemerataan karunia Allah dan juga merupakan solidaritas sosial, pernyataan rasa kemanusiaan dan keadilan, pembuktian persaudaraan Islam, sebagai pengikat bantin antara golongan kaya dengan miskin dan sebagai penghilang jurang yang menjadi pemisah antara golongan yang kuat dengan yang lemah. (Andri Soemitra, 2009:404)

Zakat sudah menjadi suatu kewajiban muslim yang harus ditunaikan dan bukan merupakan hak, sehingga kita tidak dapat memilih untuk membayar atau tidak. Zakat memiliki aturan yang jelas mengenai harta apa yang harus 
dizakatkan, batasan harta yang dikenakan zakat, demikian juga perhitungannya, karena memiliki persyaratan dan aturan baku baik alokasi, sumber, besaran maupun waktu tertentu yang telah ditetapkan oleh syariah. (Wasilah dan Nurhayati Sri, 2011:278)

\section{Corporate Social Responsibility (CSR)}

Menurut Edi Suhartono, Corporate Social Responsibility (CSR) adalah suatu kepedulian organisasi bisnis untuk bertindak dengan caracara mereka sendiri dalam melayani kepentingan organisasi dari kepentingan punlik eksternal. Perusahaan mengintegrasikan kepedulian sosial dalam operasi bisnis mereka dan dalam interaksi mereka dengan pemangku kepentingan berdasarkan prinsip sukarela dan kemitraan. (Hamdani, 2011:174)

CSR dalam persfektif Islam merupakan konsekuensi inhern dari ajaran Islam itu sendiri. Tujuan dari syariat Islam (Maqhasid al syariah) adalah maslahah sehingga bisnis adalah upaya untuk menciptakan maslahah, bukan sekedar mencari keuntungan.

Aktivitas-aktivitas sosial dari bank syariah merupakan nilai tambah (add value) yang dapat berimplikasi pada meningkatnya profitabilitas jangka panjang dan goodwill yang diperoleh dari citra positif dari bisnis yang dijalankan serta meningkatnya kepercayaan stakehilder terhadap kinerja bank syariah. Jika CSR tidak dilaksanakan maka akan terdapat lebih banyak biaya yang harus ditanggung perusahaan.

Sebaliknya jika melaksanakan CSR dengan baik dan aktif bekerja keras mengimbangi hak-hak dari semua stakeholders berdasarkan kewajaran, martabat, keadilan dan memastikan distribusi kekayaan yang adil dan akan memberi manfaat dalam jangka panjang terutama bagi perusahaan, masyarakat dan pemerintah. (Hamdani, 2011:174)

\section{Bank Umum Syariah}

Menurut Undang-Undang Republik Indonesia No. 10 Tahun 1998, tentang perubahan atas Undang-Undang No. 7 Tahun 1992 tentang perbankan, Bank umum syariah adalah bank yang melakukan kegiatan usaha berdasarkan prinsip syariah yang dalam kegiatannya memberikan jasa dalam lalulintas pembayaran. Adapun peranan bank umum yaitu: (Herman Darmawi, 2006:46)

1) Menyediakan berbagai jasa perbankan Bank menjual produk yang bermacam ragam diantaranya yaitu produk tabungan, deposito, kredit dan giro. Bank umum juga menjual jasa cek wisata, pengiriman uang, inkaso, kartu kredit, ATM, jual beli valuta asing, jasa penyimpanan barangbarang berharga, menerbitkan garansi bank, menyelenggarakan dana pensiun dan lain sebagainya.

2) Sebagai jantungnya perekonomian Dipandang dari segi perekonomian bankbank umum berperan sebagai jantungnya perekonomian negara. Uang (ibaratnya darah perekonomian) mengalir kedalam bank, kemudian oleh bank diedarkan kembali kedalam sistem perekonomian agar perekonomian tetap berjalan dan proses ini berlangsung terus menerus tanpa henti. 
3) Melaksanakan Kebijakan Moneter

Bank umum berperan pula untuk mengefektifkan kebijaksanaan pemerintah dibidang perekonomian melalui pengendalian jumlah uang yang beredar dengan mematuhi cadangan wajib. Jika jumlah uang berlebih inflasi akan terjadi disertai dengan akibat-akibat buruk yang akan mengganggu perekonomian. Sebaliknya jika jumlah uangyang beredar terlalu berkurang akan menyebabkan perlambatan proses perekonomian.

Dalam menjalankan peranannya ini, bank umum harus melakukan fungsi-fungsinya. Fungsi-fungsi yang dilakukan bank umum dapat digolongkan sebagai berikut: (Herman Darmawi, 2006:47-49)

a. Menghimpun dana dari tabungan masyarakat

b. Memberikan pinjaman

c. Mekanisme pembayaran

d. Mekanisme uang giral

e. Menyediakan fasilitas untuk memperlancar perdagangan luar negeri

\section{Industri Keuangan Syariah Di Indonesia}

\section{a. Bank Syariah}

Bank merupakan perusahaan yang bergerak dibidang keuangan, artinya aktivitas perbankan selalu berkaitan dalam bidang keuangan. Sehingga berbicara mengenai bank tidak terlepas dari masalah keuangan.

Bank syariah adalah bank yang aktivitasnya meninggalkan masalah riba. Penghindaran bunga yang dianggap riba merupakan salah satu tantangan yang dihadapi dunia Islam sekarang ini.
Bank yang berdasarkan syariah Islam (Bank Islam) adalah lembaga perbankan yang menggunakan sistem dan operasinya berdasarkan syariah Islam. Hal ini berarti operasi perbankan mengikuti tata cara berusaha maupun perjanjian berusaha berdasarkan Al-qur'an dan Sunah Rasulullah SAW dan bukan tata cara dan perjanjian berusaha yang bukan dituntut oleh $\mathrm{Al}$ qur'an dan Sunnah Rasul Muhammad SAW. Dalam operasinya Bank Islam menggunakan sistem bagi hasil dan imbalan lainnya yang sesuai dengan syariah Islam. (Jumal Lulail Yunus, 2009:30)

\section{b. Prinsip Operasi Bank Syariah}

Produk bank tanpa bunga tak jauh berbeda dengan bank biasa hanya filosofi dan sistemnya yang berbeda. Pada bank Islam, pemilik dana menanamkan uangnya di bank tetapi dalam rangka beramal. Dana nasabah akan disalurkan pada oranglain yang membutuhkan lewat bank, lalu keuntungan akan dibagi sesuai perjanjian. Khusus untuk pembiayaan berbentuk musyarakah, apabila dirugikan akan ditanggung bersama oleh bank dan nasabah.

Keberadaan bank syariah disebut dalam Undang-Undang Perbankan Tahun 1992 yang pelaksanaannya diatur dengan peraturan Pemerintah Nomor 72 Tahun 1992. Bank syariah pun dinamakan sebagai bank tanpa bunga karena dalam menghimpun dana tidak memberi imbalan bunga dan dalam pinjaman pinjaman tidak dipungut bunga. Prinsip operasi bank syariah berdasarkan prinsip wadi'ah, mudharabah, musyarakah, murabahah, bai' bhitaman ajil, ijarah, qardul hasan, bai' al dayan, kafalah, rahn, hiwalah dan wakalah. (Jumal Lulail Yunus, 2009:81) 


\section{c. Faktor Yang Mempengaruhi Kinerja Bank}

Pada umumnya, penilaian kinerja perbankan dapat menggunakan rasio-rasio yang ada pada masing-masing laporan keuangan bank yang bersangkutan, berbagai rasio yang dihitung untuk menilai kinerja suatu bank dikelompokkan kedalam empat tipe dasar yaitu: (Lukman Dendawijaya, 2009:120)
a. Rasio Likuiditas
b. Rasio Profitabilitas atau Rentabilitas
C. Rasio Solvabilitas
d. Rasio Aktivitas

\section{METODE PENELITIAN}

Penelitian ini dilakukan pada Bank Umum Syariah di Indonesia melalui situs resmi BI www. bi.go.id dan OJK www.ojk.go.id. Penelitian ini adalah penelitian kuantitatif, sumber data dalam penelitian ini adalah data sekunder dengan bentuk data time series dan cross section sebanyak 54 sampel. Teknik pengumpulan data adalah dokumentasi melalui laporan publikasi pada situs resmi Otoritas Jasa Keuangan dan Bank Indonesia. Teknik analisis data menggunakan metode estimasi data panel dengan uji statistik deskriptif, uji asumsi klasik, uji hipotesis dan analisis regresi linier berganda, dengan pengolahan data digunakan melalui program Eviews 9.

Analisis regresi berganda digunakan untuk mengetahui keeratan hubungan antara variabel dependen (Return On Asset) dengan variabel independen (Zakat Perbankan dan Corporate Social Responsibility).

\section{PEMBAHASAN DAN HASIL}

Secara parsial, zakat perbankan memiliki nilai $t_{\text {hitung }}>t_{\text {tabel }}(2.915948>1.67528)$, maka dapat disimpulkan zakat perbankan secara parsial berpengaruh signifikan terhadap return on asset bank umum syariah di indonesia 2013-2018. Corporate social responsibility memiliki nilai $\mathrm{t}_{\text {hitung }}<$ $\mathrm{t}_{\text {tabel }}(-0.677166<1.67528)$ maka dapat disimpulkan corporate social responsibility secara parsial tidak berpengaruh signifikan terhadap return on asset Bank Umum Syariah di Indonesia 2013-2018.

Secara simultan, zakat perbankan dan corporate social responsibility memiliki nilai $\mathrm{F}_{\text {hitung }}$ $>\mathrm{F}_{\text {tabel }}(10.14220>3.18)$ maka dapat disimpulkan bahwa zakat perbankan dan corporate social responsibility secara simultan mempengaruhi zakat bank umum syariah di indonesia. Hasil koefisien determinasi $\left(\mathrm{R}^{2}\right)$ diperoleh $\mathrm{R}^{2}$ sebesar 0.633020 . Hal ini menunjukkan $63.30 \%$ setiap pertumbuhan zakat perbankan dapat dijelaskan oleh variabel zakat perbankan dan corporate social responsibility sisanya $36.70 \%$ diterangkan oleh variabel lain yang tidak dimasukkan dalam penelitian ini.

Persamaan regresi linear berganda dengan 2 variabel independen sebagai berikut :

Berdasarkan output:

$$
\begin{aligned}
\mathrm{ROA}= & (-) 5.301905+0.432333 \mathrm{ZKT}+(-) \\
& 0.085527 \mathrm{CSR}
\end{aligned}
$$

Artinya :

a) Konstanta sebesar 5.301905 artinya apabila variabel ZKT CSR dianggap konstan atau 0 maka nilai ROA sebesar 5.301905.

b) Nilai koefisien ZKT sebesar 0.432333 dengan nilai positif. Hal ini berarti bahwa 
setiap peningkatan 1 satuan ZKT maka ROA meningkat sebesar 0.432333 satuan dengan asumsi variabel lain konstan.

c) Nilai koefisien CSR sebesar 0.085527 dengan nilai negatif. Hal ini berarti bahwa setiap peningkatan 1 satuan CSR maka ROA menurun sebesar 0.085527 satuan dengan asumsi variabel lain konstan.

\section{PENUTUP}

Berdasarkan hasil penelitian, maka peneliti mengambil kesimpulan sebagai berikut:

1. Secara parsial, variabel Zakat Perbankan memiliki nilai $t_{\text {hitung }}>\mathrm{t}_{\text {tabel }}(2.915948$ $>$ 1.67528) maka dapat disimpulkan $\mathrm{H}_{0}$ ditolak $\mathrm{H}_{\mathrm{a}}$ diterima. Jadi dari uji tersebut dapat disimpulkan bahwa variabel Zakat Perbankan secara parsial berpengaruh signifikan terhadap return on asset Bank Umum Syariah di Indonesia 2013-2018.

2. Secara parsial, variabel Corporate Social Responsibility memiliki nilai $\mathrm{t}_{\text {hitung }}<\mathrm{t}_{\text {tabel }}$ $(-0.677166<1.67528)$ maka dapat disimpulkan $\mathrm{H}_{0}$ diterima dan $\mathrm{H}_{\mathrm{a}}$ ditolak. Jadi dari uji tersebut dapat disimpulkan bahwa variabel Corporate Social Responsibility secara parsial tidak berpengaruh signifikan terhadap return on asset Bank Umum Syariah di Indonesia 2013-2018.

3. Secara simultan, variabel Zakat Perbankan dan Corporate Social Responsibility memiliki nilai $\mathrm{F}_{\text {hitung }}>\mathrm{F}_{\text {tabel }}(10.14220>3,18)$ yang berarti bahwa kedua variabel tersebut secara simultan mempengaruhi variabel return on asset Bank Umum Syariah di Indonesia 2013-2018.

\section{DAFTAR PUSTAKA}

Abdul Nasser Hasibuan, Strategi Pemasaran produk funding di PT.Pembiayaan Rakyar Syariah Padangsidimpuan, Jurnal Imara: 2018, http://ecampus.iainbatusangkar. ac.id/ojs/index.php/jurei/article / view/1032/1046

Andri Soemitra, Bank dan Lembaga Keuangan Lainnya, Jakarta:Kencana, 2009.

Anggota Ikapi, Undang-Undang Perbankan Syariah dan Surat Berharga Syariah Negara, Bandung: FokusMedia, 2008.,

Didin Hafidhuddin, Zakat Dalam Perekonomian Modern, Jakarta: Gema Insani Press, 2002. Agar Harta Bertambah Berkah, Jakarta: Gema Insani Press, 2007.

Hendrik Budi Untung, Corporate Social Responsibility, Jakarta: Sinar Grafika, 2009.

Herman Darmawi, Pasar Finansial dan LembagaLembaga Finansial,Jakarta: PT.BumiAksara, 2006. Hery, Analisis Laporan Keuangan, Yogyakarta: CAPS, 2015.

IrhamFahmi, Analisis Laporan Keuangan, Bandung: Alfabeta, 2015.

Jumal Lulail Yunus, Manajemen Bank Syariah Mikro, Malang: UIN-Malang Press, 2009.

Jumingan, Analisis Laporan Keuangan, Jakarta: PT Bumi Aksara, 2011.

Kasmir, Bank dan Lembaga Keuangan Lainnya, Jakarta: PT, Raja Grafindo Persada, 2007 , Manajemen Perbankan, Jakarta: Rajawali, 2008. 
JURNAL IMARA

Lukman Dendawijaya, Manajemen Perbankan, Wasilah dan Nurhayati Sri, Akuntansi Syariah di Jakarta: Ghalia Indonesia, 2009 Indonesia: Edisi 2 Revisi, Jakarta: Salemba

Rizal Yaya, Akuntansi Perbankan Syariah Edisi 2, Empat, 2011.

Jakarta: Salemba Empat, 2016

Wiratna Sujarweni, Metodologi Penelitian,

Umrotul Khasanah, Manajemen Zakat Modern: Yogyakarta: PustakaBaru Press, 2014.

Instrumen Pemberdayaan Ekonomi Umat, Malang: UIN-Maliki Press, 2010.

$70 \mid$ Windari, Abdul Nasser Hasibuan 